\section{Folliculostellate cells in pituitary pars distalis of male viscacha: immunohistochemical, morphometric and ultrastructural study}

\author{
Mariano Acosta, Verónica Filippa, \\ Fabian Mohamed \\ Cátedra de Histología y Embriología, \\ Facultad de Química, Bioquímica y \\ Farmacia, Universidad Nacional de San \\ Luis, Consejo Nacional de Investigaciones \\ Científicas y Técnicas (CONICET), \\ San Luis, Argentina
}

\section{Abstract}

Folliculostellate cells (FSC) have been reported in pituitary of several mammalian species. FSC morphology and secreted substances have been instrumental to the understanding of their function. The purpose of this work was to perform an immunohistochemical, morphometric and ultrastructural study of the pituitary pars distalis FSC in adult male viscacha and to analyze their relation with hormone secreting cells. Immunohistochemistry and image analysis were carried out in different sectors of the gland, from the middle (sector 1) to the glandular periphery (sector 5). Transmission electron microscopy with lanthanum as electrodense tracer was used. FSC formed follicles with PAS-positive colloid inside. They expressed S-100 protein mainly in both nucleus and cytoplasm. FSC were stellate-like in shape and exhibited short cytoplasmic processes that contacted with blood vessels and endocrine cells. In addition, some follicular colloids were immunostained with anti-S-100 protein. A few FSC were immunostained with anti-glial fibrillary acidic protein (GFAP) and anti-vimentin. The morphometric parameters analyzed (percentages of S-100positive total, cellular and colloidal areas) increased from sector 1 to sector 3 and then decreased to sector 5. Hormone secreting cells, mainly lactotrophs, gonadotrophs and corticotrophs were associated with FSC and follicles. The ultrastructural study demonstrated that FSC developed junctional complexes and desmosomes between their lateral membranes. Lanthanum freely penetrated the spaces between granulated cells and FSC, but did not penetrate into the follicular lumen. In conclusion: 1) the differential expression of S100 protein, GFAP and vimentin may indicate different physiological stages of FSC; 2) the expression of these proteins suggests a neu- roectodermic origin of these cells; 3) FSC spatial distribution, association with endocrine cells, and the generation of an intercellular communication network suggest that FSC are involved in the pituitary pars distalis paracrine regulation of the viscacha.

\section{Introduction}

Pituitary folliculostellate cells (FSC) have been reported in several mammalian species. ${ }^{1}$ At present, however, there is no agreement in the literature in relation with the embryological origin and exact function of these cells. In fact, FSC have been reported to play a supporting role, to have phagocytotic activity, and to act as regulators of hormone secretion and as stem cells. ${ }^{2-5}$ FSC have been found lining the lumen of follicles scattered throughout the pituitary pars distalis. ${ }^{5-9}$ The FSC have been studied using the antibody against S-100 protein, in both mammalian ${ }^{6-12}$ and non-mammalian species. ${ }^{3,4,13}$ In addition, some authors have reported in human, ${ }^{11}$ cat, rat and rabbit ${ }^{14}$ and mink ${ }^{7}$ that FSC were immunostained with anti-glial fibrillary acidic protein (GFAP) and anti-vimentin. However, in pituitary of dog and horse these cells did not express GFAP and vimentin, but they expressed the S-100 protein. ${ }^{15}$ Soji et al. ${ }^{6}$ have shown an increase in the number of these cells in relation with age, suggesting that the expression of the $\mathrm{S}$ 100 protein indicates the cell morphologic maturation stage in rats. Moreover, several authors have demonstrated the existence of different physiological stages of FSC based on their morphological characteristics and immunophenotype. ${ }^{7,11,16}$

On the other hand, there are few reports in the literature on the distribution of FSC in the pituitary parenchyma. Sato et al. ${ }^{12}$ have reported that FSC are mainly localized in the basal region and transition zone of rat pituitary and also showed an association between FSC distribution and vascularization.

Furthermore, FSC have been reported to synthesize part of the follicular colloid and a close relationship has been described between these cells, the follicular colloid and hormone secreting cells. ${ }^{3,4,16-18}$

Ultrastructurally, FSC share distinct characteristics in all studied species. They exhibit scanty cytoplasm with poorly developed endoplasmic reticulum, inconspicuous Golgi complex, moderate amount of mitochondria and absence of the secretory granules. ${ }^{1}$ Some studies in pituitary have also been performed with lanthanum as electrodense tracer. ${ }^{19,20}$

Our experimental model is the viscacha (Lagostomus maximus maximus), the largest
Correspondence: Fabian Mohamed, Cátedra de Histología y Embriología, Facultad de Química, Bioquímica y Farmacia, Universidad Nacional de San Luis, Avenida Ejército de los Andes 950 - $2^{\circ}$ piso. CP 5700, San Luis, Argentina.

E-mail: fhmo@unsl.edu.ar

Key words: Lagostomus, pituitary, folliculostellate cells, immunohistochemistry, distribution, ultrastructure.

Acknowledgments: we wish to thanks Dr. R. Piezzi, Mrs. T. Fogal, Mrs. A. Bernardi and Mr. J. Arroyuelo for their technical collaboration. The financial support for this study was received from CONICET and Universidad Nacional de San Luis (grant number 22/Q603).

Received for publication: 28 July 2009.

Accepted for publication: 24 November 2009.

This work is licensed under a Creative Commons Attribution 3.0 License (by-nc 3.0).

(C) Copyright M. Acosta et al., 2010

Licensee PAGEPress, Italy

European Journal of Histochemistry 2010; 54:e1 doi:10.4081/ejh.2010.e1

member of the Chinchillidae family. This rodent inhabits the southern hemisphere from Paraguay through central Argentina. ${ }^{21,22}$ In its natural habitat, the viscacha is a seasonal breeder. ${ }^{23-27}$ The pituitary pars intermedia (PI), pineal gland, and blood-testis barrier of this rodent have been studied using lanthanum. ${ }^{28-30}$ Piezzi et al. ${ }^{28}$ have demonstrated the permeability to lanthanum and the communication of the PI parenchyma with Rathke's pouch. In this pituitary zone, the FSC originated follicles with PAS-positive colloid inside, expressed S-100, GFAP and vimentin, and were closely associated with melanotrophs. ${ }^{31}$ Moreover, an ultrastructural study of the pituitary PD has demonstrated the existence of two types of colloid-containing structures: 1) follicles, originated by the FSC, and 2) colloid extracellular accumulations, limited by different types of granulated cells. ${ }^{32}$ The follicular lumen was filled with abundant electrodense colloid and several cellular debris comprising vacuoles, altered membranes, mitochondria and secretory granules, which are probably a product of FSC phagocytotic activity. ${ }^{32}$ In addition, the hormone secreting cells have exhibited regionalization within the PD parenchyma. ${ }^{27,33-36}$

Based on the above data and our previous knowledge about the viscacha pituitary, the aim of this work was to perform an immunohistochemical, morphometric and ultrastructural study of the pituitary pars distalis FSC in adult male viscacha and to analyze their relation with hormone secreting cells. 


\section{Materials and Methods}

Fourteen adult male viscachas weighing 6.0$6.5 \mathrm{~kg}$ were captured in their habitat near San Luis, Argentina ( $33^{\circ} 20^{\prime}$ south latitude, $760 \mathrm{~m}$ altitude) during February-March 2008 (summer), using traps placed in their burrows. According to the results published by Llanos and $\mathrm{Crespo}^{37}$ and Branch et al. ${ }^{38}$ the body weight of this rodent is in relation with its age. Then, the viscachas used in this study were in the same growth stage. After being captured, animals were immediately taken to the laboratory, anaesthetized with Nembutal (pentobarbital; $25 \mathrm{mg} / \mathrm{Kg}$ ip.) and killed by decapitation. The brains were rapidly exposed and the pituitaries (weighing 28-30 mg) were excised. The experimental design was approved by the Local Ethics Committee and was in agreement with the Guidelines of the National Institutes of Health (Bethesda, Md., USA) for the use of experimental animals.

For light microscopy, the pituitaries $(n=6)$ were sectioned in the middle plane (Figure 1, line M). Both halves of each pituitary were fixed in Bouin's fluid, dehydrated in increasing graded ethanol, cleared in xylene, embedded in paraffin and five- $\mu \mathrm{m}$ thick sections were obtained with a microtome (Microm HM 325). Periodic acid-Schiff (PAS) technique was assayed and the sections were examined using an Olympus BX-40 light microscope.

\section{Immunohistochemistry}

The streptavidin-biotin immunoperoxidase method was used as described previously. ${ }^{27,31,33-}$ ${ }^{36}$ The details, suppliers, dilution, time and temperature of the incubation of antibodies used are reported in Table 1. The tissue sections were first deparaffinized with xylene and hydrated by decreasing concentrations of ethanol. The microwave pre-treatment (antigen retrieval) was performed by incubating the sections in $0.01 \mathrm{M}$ citrate buffer $(\mathrm{pH} 6.0)$. After incubation for 20 min in a solution of $3 \% \mathrm{H}_{2} \mathrm{O}_{2}$ in water in order to inhibit endogenous peroxidase activity, they were washed (3x10 min) in phosphate-buffered saline (PBS, $0.01 \mathrm{M}, \mathrm{pH}$ 7.4). Non-specific binding sites for immunoglobulins were blocked by 15 min-incubation with $0.25 \%$ casein in PBS, washed in PBS and incubated with the primary antibodies. The slides were subsequently washed $(3 \times 10 \mathrm{~min})$ in PBS. The immunohistochemical visualization was carried out using the Super Sensitive Ready-to-Use Immunostaining Kit (Catalog $n^{0}$ : QD000-5L; BioGenex, San Ramon, Calif., USA) at $20^{\circ} \mathrm{C}$. The sections were incubated for $30 \mathrm{~min}$ with biotinylated anti-IgG, and after being washed ( $3 \times 5 \mathrm{~min})$ in PBS, they were incubated for $30 \mathrm{~min}$ with horseradish peroxidase-conjugated streptavidin, and finally washed in PBS.

Table 1. Features of the antibodies used for immunohistochemical study.

\begin{tabular}{|c|c|c|c|}
\hline Antibody & $\begin{array}{l}\text { Immunostained } \\
\text { cellular type }\end{array}$ & $\begin{array}{l}\text { Clone, catalog } \\
\text { and source }\end{array}$ & $\begin{array}{l}\text { Time, Temperature } \\
\text { Incubation }\end{array}$ \\
\hline Anti-S-100 protein & Folliculostellate cell (FSC) & $\begin{array}{l}\text { Polyclonal. AR058-5R. } \\
\text { Ready-to-Use. BioGenex }\end{array}$ & $12 \mathrm{~h}, 4^{\circ} \mathrm{C}$ in a moist chamber \\
\hline $\begin{array}{l}\text { Anti-GFAP } \\
\text { (glial fibrillary } \\
\text { acidic protein) }\end{array}$ & FSC & $\begin{array}{l}\text { Polyclonal. AR020-5R. } \\
\text { Ready-to-Use. BioGenex }\end{array}$ & $12 \mathrm{~h}, 4^{\circ} \mathrm{C}$ in a moist chamber \\
\hline Anti-Vimentin & FSC & $\begin{array}{l}\text { V9. AM074-5M. } \\
\text { Ready-to-Use. BioGenex }\end{array}$ & $12 \mathrm{~h}, 4^{\circ} \mathrm{C}$ in a moist chamber \\
\hline Anti-Prl (prolactin) & Lactotroph & $\begin{array}{l}\text { Polyclonal. N1549. } \\
\text { Ready-to-Use. } \\
\text { DakoCytomation }\end{array}$ & $60 \mathrm{~min}, 4^{\circ} \mathrm{C}$ in a moist chamber \\
\hline $\begin{array}{l}\text { Anti-FSH } \beta \\
\text { (follicle stimulating } \\
\text { hormone) }\end{array}$ & $\begin{array}{l}\text { FSH-gonadotroph } \\
\text { MU026-UC. }\end{array}$ & $\begin{array}{l}\text { 83/12/ 2A8 2C7. } \\
\text { 1:100. BioGenex }\end{array}$ & $12 \mathrm{~h}, 4^{\circ} \mathrm{C}$ in a moist chamber \\
\hline $\begin{array}{l}\text { Anti-LH } \beta \\
\text { (luteinizing } \\
\text { hormone) }\end{array}$ & LH-gonadotroph & $\begin{array}{l}\text { 3LH 5B6 YH4. AM030-5M. } \\
\text { 1:200. BioGenex }\end{array}$ & $12 \mathrm{~h}, 4^{\circ} \mathrm{C}$ in a moist chamber \\
\hline $\begin{array}{l}\text { Anti-ACTH (1-24) } \\
\text { (adrenocorticotropin } \\
\text { hormone) }\end{array}$ & Corticotroph & $\begin{array}{l}\text { Polyclonal. AR035-5R. } \\
\text { Ready-to-Use. BioGenex }\end{array}$ & $60 \mathrm{~min}, 4^{\circ} \mathrm{C}$ in a moist chamber \\
\hline $\begin{array}{l}\text { Anti-GH } \\
\text { (growth hormone) }\end{array}$ & Somatotroph & $\begin{array}{l}\text { Polyclonal. N1561. } \\
\text { Ready-to-Use. } \\
\text { DakoCytomation }\end{array}$ & $12 \mathrm{~h}, 4^{\circ} \mathrm{C}$ in a moist chamber \\
\hline $\begin{array}{l}\text { Anti-TSH } \\
\text { (thyroid stimulating } \\
\text { hormone) }\end{array}$ & Thyrotroph & $\begin{array}{l}\text { 5404. AM033-5M. } \\
\text { Ready-to-Use. BioGenex }\end{array}$ & $12 \mathrm{~h}, 4^{\circ} \mathrm{C}$ in a moist chamber \\
\hline
\end{tabular}

The reaction site was revealed by $100 \mu \mathrm{L} 3,3^{\prime}$ diaminobenzidine tetrahydrochloride (DAB) chromogen solution in $2.5 \mathrm{ml}$ PBS and $50 \mu \mathrm{L}$ $\mathrm{H}_{2} \mathrm{O}_{2}$ substrate solution, resulting in a brown precipitate. The sections were counterstained with Harris' hematoxylin for $30 \mathrm{~s}$, washed 10 min in running water, dehydrated in increasing graded ethanol, cleared in xylene and mounted with Entellan (Merck, Germany). Labeling was assessed using an Olympus BX-40 light microscope. To confirm the specificity of the immunoreactions the following control procedures were carried out: 1) replacement of primary antibody with normal goat serum, and 2) omission of primary antibody. No positive structures or cells were found in these sections.

\section{Morphometric analysis}

Morphometric parameters were measured with a computer-assisted image analysis system consisting of an Olympus BX-40 binocular microscope, interfaced with a host computer, image processing and recording system. The images were captured by a Sony SSC-DC50A camera and processed with Image Pro Plus 5.0 software under control of a Pentium IV computer. The software allowed the following processes: images acquisition, automatic analogous adjust, thresholding, background subtraction, distance calibration, area measuring and diskette data logging. Before counting, a reference area of $3,000 \mu \mathrm{m}^{2}(\times 100$ objective $)$ was defined on the colour monitor, and distance calibration was performed using a slide with a micrometric scale for microscopy (Reichert, Austria).

For the morphometric analysis, all hemipituitaries were cut from the line $M$ (Figure 1) to the glandular periphery (lines $\mathrm{P}$ and $\mathrm{P}$ '), and 400 sections (5 $\mu \mathrm{m}$ thick) were obtained in each one. All the serial sections were grouped into 5 sectors (80 sections per sector) and 8 regularly spaced serial sections (50 $\mu \mathrm{m}$ each) were analyzed in every sector. All the microscopic fields captured with $\times 100$ objective were analyzed in each section (340 microscopic fields per section). Therefore, 13,600 microscopic fields were analyzed in each hemipituitary. The following morphometric parameters were determined: *Percentage of S-100-positive total area (\%IA S-100): calculated using the formula $\% \mathrm{IA}=\Sigma \mathrm{Ai} / \mathrm{IM} \mathrm{RA} \times 100$, where $\Sigma$ Ai was the sum of the S-100-positive area and $\Sigma$ RA was the sum of the PD area of every microscopic field. *Percentage of S-100-positive cellular area (\%IA S-100 cel): calculated using the formula $\% \mathrm{IA}=\Sigma$ Acel $/ \Sigma \mathrm{RA} \times 100$, where $\Sigma$ Acel was the sum of the area of S-100-positive cells and $\Sigma$ RA was the sum of the PD area of every microscopic field. *Percentage of S-100-positive colloidal area (\%IA S-100 col): calculated using the formula $\% \mathrm{IA}=\Sigma$ Acol $/ \Sigma \mathrm{RA} \times 100$, where $\Sigma$ Acol was the sum of the area of S-100-positive follicular colloids and $\Sigma$ RA was the sum of the PD area of every microscopic field. 


\section{Statistical analysis}

The results were expressed as mean \pm standard error of the mean (SEM) for all data sets. The different groups were evaluated using one-way analysis of variance (ANOVA) followed by Tukey-Kramer multiple comparison test. A probability of less than 0.05 was assumed to be significant.

\section{Double-immunohistochemistry}

This technique was performed to examine the association between pituitary hormone secreting cells and S-100-positive FSC. The features of the antibodies are reported in Table 1. DAB and New Fuchsin were selected as chromogens to visualize the antigens because this combination is known to give good contrast. The reaction sites of the first primary antibody (against Prl, FSH, LH, ACTH, GH and $\mathrm{TSH}$ ) were revealed following the procedure described in the Immunohistochemistry section, using DAB as chromogen. For the second labeling, the slides were washed ( $3 \times 10 \mathrm{~min})$ in $0.1 \mathrm{M}$ glycine- $\mathrm{HCl}$ buffer $(\mathrm{pH} 2-2.2)$ at $20^{\circ} \mathrm{C}$ for 70 min, washed in PBS, and finally incubated with the second primary antibody (against $\mathrm{S}$ -

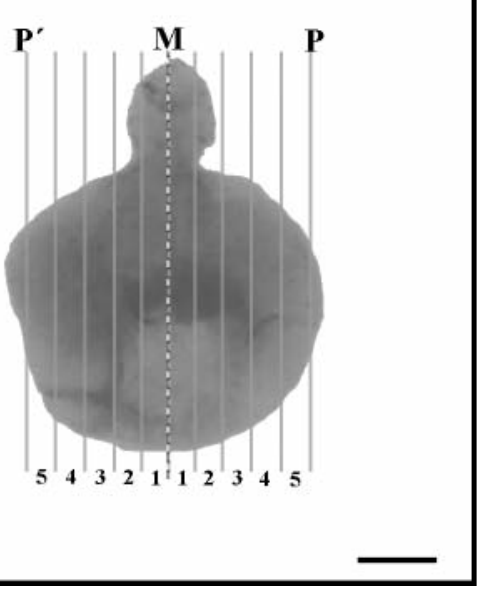

Figure 1. Recently removed pituitary of adult male viscacha captured in February (summer). Line $M$ represents vertical cut to obtain two hemipituitaries, and the lines $P$ and $P^{\prime}$ correspond to the glandular periphery extremes. The regularly spaced serial sections were grouped in five sectors (1 to 5) in each hemipituitary. Scale bar = $0.1 \mathrm{~mm}$.
100 protein). Then, the slides were washed (3x10 min) in PBS, and the sections were incubated for $30 \mathrm{~min}$ with biotinylated antiIgG, washed ( $3 \times 5 \mathrm{~min})$ in PBS, and incubated 30 min with alkaline phosphatase-conjugated streptavidin. The sections were washed in PBS for $10 \mathrm{~min}$, and the reaction sites were revealed by $100 \mu \mathrm{L}$ New Fuchsin Chromogen Kit (Catalog $n^{0}$ HK 183-5K; BioGenex), result- ing in a fuchsia precipitate. The sections were counterstained with Harris' hematoxylin for 30 $\mathrm{s}$, washed $10 \mathrm{~min}$ in running water and mounted with permanent aqueous mounting medium (SuperMount, BioGenex). Labeling was assessed using an Olympus BX-40 light microscope. The specificity of the immunoreaction was confirmed following the above described protocol (see Immunohistochemistry).
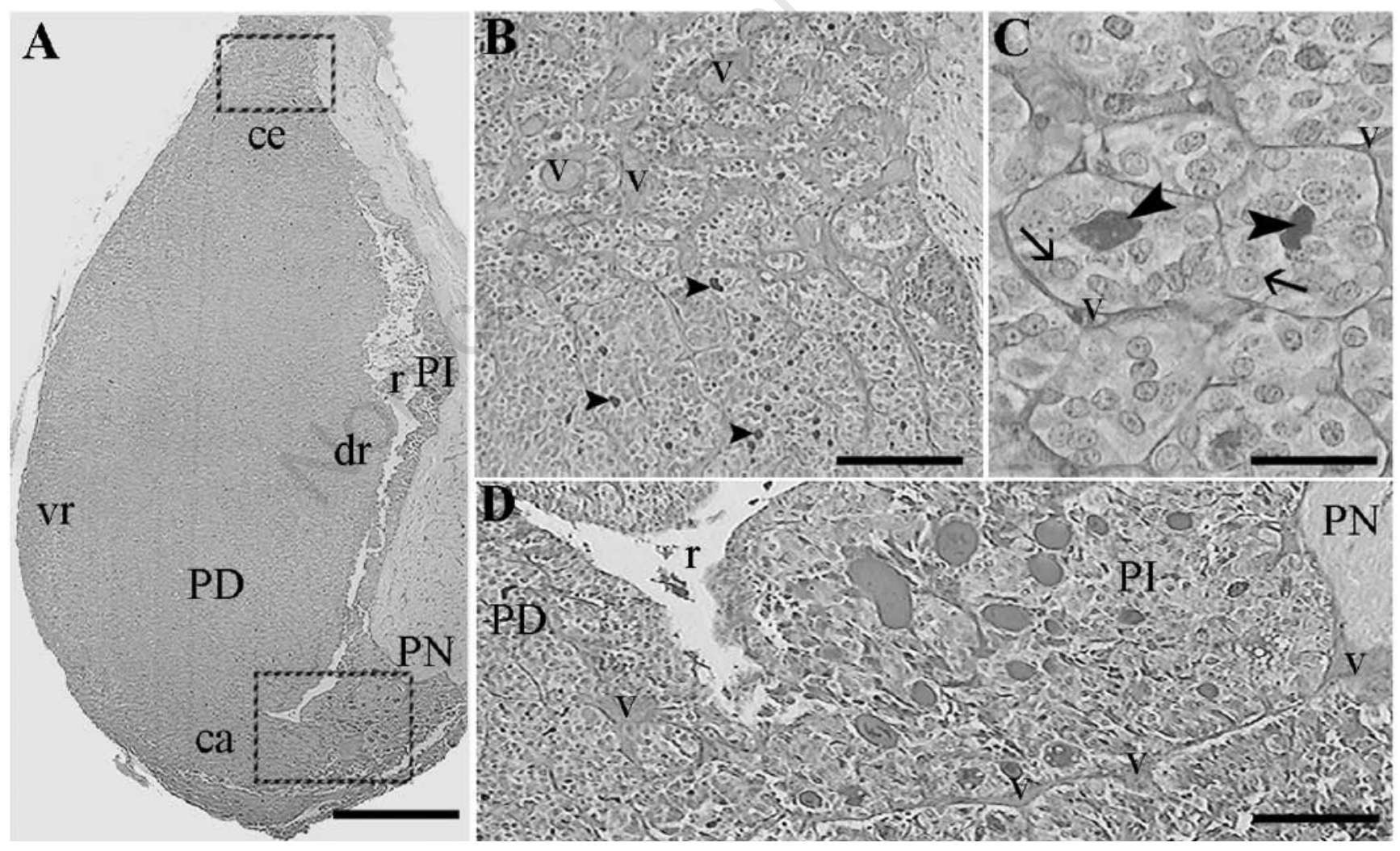

Figure 2. Sections of the pituitary of adult male viscacha stained with Hematoxylin-PAS technique. (A) The image shows: pars distalis (PD), pars intermedia (PI), pars nervosa (PN) and Rathke's pouch (r). The regions and extremes of the pituitary PD are shown: vr, ventral region; dr, dorsal region; ce, cephalic extreme; ca, caudal extreme. (B) Higher magnification of the upper insert in Figure A. Long blood vessels (v) branch out in PD are observed. Arrowheads: PAS-positive colloid. (C) The follicles with PAS-positive colloids inside (arrowheads) are surrounded by one or two layers of endocrine cells (arrows) and blood vessels (v). (D) Higher magnification of the lower insert in Figure A. Blood vessels (v) that communicate pars distalis (PD) with both pars intermedia (PI) and pars nervosa (PN) are observed. r: Rathke's pouch. Scale bars: $A=500 \mu \mathrm{m} ; \mathrm{B}$ and $\mathrm{D}=100 \mu \mathrm{m} ; \mathrm{C}=25 \mu \mathrm{m}$. 


\section{Transmission electron microscopy}

Eight adult male viscachas were anaesthetized with Nembutal (pentobarbital; 25 $\mathrm{mg} / \mathrm{kg}$ ip.), killed by decapitation and the brain was rapidly exposed. The pituitaries $(n=4)$ were fixed in a mixture of $3 \%$ glutaraldehyde and $4 \%$ formaldehyde, pH 7.6 with $\mathrm{PBS},{ }^{39}$ postfixed in cold $2 \%$ 0s04, processed for transmission electron microscopy, dehydrated in acetone, and embedded in Spurr's resin.

In the remaining animals $(n=4)$, a small volume of the fixative-lanthanum mixture prepared as described below was injected in situ into the pituitary cleft. This procedure was controlled under a stereo microscope. In order to use lanthanum as an intercellular tracer, the method described by Revel and Karnovsky ${ }^{40}$ was adopted. A 4\% lanthanum nitrate solution was adjusted to $\mathrm{pH}$ 7.7-7.8 by slowly adding sodium hydroxide $(0.05 \mathrm{~N})$. The lanthanum hydroxide thus obtained was incorporated to an equal volume of s-collidine buffered glutaraldehyde, so that the final concentration of lanthanum was $2 \%$. Then, the pituitary was removed and immersed for an additional $6 \mathrm{~h}$-period in the same solution, post-fixed in cold $2 \% \mathrm{OsO}_{4}$ for 2 hours, dehydrated in acetone, and embedded in Spurr's resin. The experimental design was carried out according to protocols previously used in viscachas in our laboratory. ${ }^{28}$

Sections of $1 \mu \mathrm{m}$ were stained with toluidine blue and observed under a light microscope (Olympus BX-40) in order to localize the area of interest. Ultra thin sections of approximately 70 $\mathrm{nm}$ thick were cut in a Porter Blum ultramicrotome, mounted on copper grids and stained with uranyl acetate and lead citrate. ${ }^{41}$ Specimens were finally examined using a transmission electron microscope (Siemens Elmiskop I).

\section{Results}

The pituitary PD of Lagostomus maximus maximus exhibited two regions: ventral (anterior) and dorsal (posterior, close to Rathke's pouch). In addition, two extremes were distinguished: a cephalic one (superior, connected with pars tuberalis) and a caudal one (inferior; Figure 2 A). The PD parenchyma showed good development of vascular irrigation and scarce connective tissue. Large blood vessels were observed in the cephalic extreme (Figure 2 B), which branched out along the PD parenchyma and anastomose in the caudal extreme, where the PD becomes narrower. Follicles with PASpositive colloid-like material inside were surrounded by one or two layers of endocrine cells and blood vessels (Figure $2 \mathrm{C}$ ). The follicles were mainly localized in the PD extremes. Some blood vessels communicated the PD with the PI and pars nervosa (PN; Figure 2 D).

\section{Immunohistochemistry}

Immunostaining for the S-100 protein was positive in FSC and some follicular colloid of PD and PI, as well as in the pituicytes of PN (Figure $3 \mathrm{~A}$ ). Most of the FSC of PD were immunostained with anti-S-100 protein in both nucleus and cytoplasm, while a few cells expressed this protein only in the nucleus or only in the cytoplasm. FSC originated follicles and were occasionally isolated or in small groups. They exhibited a stellate-like shape, irregular nucleus and short cytoplasmic processes that contacted endocrine cells and blood vessels. Most of the follicles in both pituitary extremes showed heterogeneous S-100 protein immunostaining of the follicular colloid (Figure 3 B-D). On the other hand, a small number of FSC in the PD parenchyma were immunostained with anti-GFAP in the cytoplasm surrounding the nucleus (Figure 3 E-F), and with anti-vimentin in the cytoplasm, mainly in the cytoplasmic processes (Figure $3 \mathrm{G}-\mathrm{H}$ ). In addition, in each follicle only a few FSC exhibited immunostaining for GFAP and vimentin. Neither GFAP nor vimentin were expressed in the follicular colloid (Figure $3 \mathrm{E}-\mathrm{H}$ ).

\section{Morphometric analysis}

The morphometric parameters varied according to the analyzed sectors. These parameters (\%IA S-100, \%IA S-100 cel, \%IA S$100 \mathrm{col})$ gradually increased from sector 1 $(0.63 \pm 0.01,0.22 \pm 0.01,0.40 \pm 0.02$, respectively) to sector $3(0.97 \pm 0.02, \quad 0.46 \pm 0.01$, $0.51 \pm 0.03$, respectively), and then decreased towards sector $5(0.47 \pm 0.01,0.28 \pm 0.01$, $0.19 \pm 0.02$, respectively). The comparison between the morphometric parameters of the different sectors is shown in Figure 4.

\section{Double-immunohistochemistry}

The hormone secreting cells of PD, mainly lactotrophs (Figure $5 \mathrm{~A}$ ), gonadotrophs (Figure 5 B-C) and corticotrophs (Figure 5 D) were found to be closely associated with FSC and follicles. Frequently, FSC cytoplasmic processes involved endocrine cells and/or were in contact with the blood vessels. Moreover, the follicular colloid was occasionally immunostained with anti-Prl and anti-LH. The somatotrophs, although widely distributed in the PD parenchyma, did not show a close association with follicular structures (Figure 5 E). Thyrotrophs, which were mainly distributed in the medial and cephalic regions, were not found in the proximity of the FSC or follicles. However, a few thyrotrophs in the caudal extreme were near the follicles (Figure $5 \mathrm{~F}$ ).

\section{Transmission electron microscopy}

FSC exhibited an irregular euchromatinic nucleus with some invaginations into the nuclear membrane, a fine cytoplasm with moderate number of mitochondria, scarce granular endoplasmic reticulum and absence of secretory granules. They completely surrounded the follicular colloid, exhibited scarce cytoplasm in the apical region, and presented cytoplasmic processes that contacted secretory cells and blood vessels. FSC were found to develop junctional complexes and desmosomes between their lateral membranes. A large number of microvilli protruded from the apical pole to the follicular lumen (Figure 6 A-B). Lanthanum injected into pituitary cleft freely penetrated between endocrine cells and FSC, but stopped below the FSC junctional complexes without penetrating the follicular lumen (Figure $6 \mathrm{C}$ F). Occasionally, endocrine cells in different involution or degeneration states presenting irregular and picnotic nucleus were reached by lanthanum (Figure $6 \mathrm{G}$ ), but the tracer did not penetrate inside healthy cells.

\section{Discussion}

In this work we have described the FSC immunostaining pattern, distribution and association with hormone secreting cells in the pituitary PD of adult male viscacha. Besides, we have shown the existence of an extensive and permeate network of intercommunicated intercellular spaces between endocrine cells and FSC.

In different mammalian species, FSC have been shown to exhibit both nuclear and cytoplasmic, ${ }^{42}$ only nuclear ${ }^{43}$ or only cytoplasmic ${ }^{9}$ immunostaining for S-100 protein. In addition, some authors have reported that they were immunostained with anti-GFAP ${ }^{1,7,11,44}$ and antivimentin. ${ }^{1,7,14}$ However, Méndez et al. ${ }^{15}$ showed that FSC did not express GFAP and vimentin in pituitary of dogs and horses. Reports in dog and mink pituitary PD have described the presence of two types of S-100-positive FSC., ${ }^{7}$ Marin et al. ${ }^{11}$ have suggested the existence of different types of FSC in human pituitary on the basis of the immunostaining pattern and localization within the parenchyma. In PI of viscacha, the FSC exhibited irregular nucleus, stellate-like shape and long cytoplasmic processes which contacted melanotrophs or communicated follicles either with each other or with Rathke's pouch. In this pituitary zone, scarce vascularization and large follicles (major colloidal diameter: $39.87 \pm 0.49 \mu \mathrm{m}$ ) have been informed. ${ }^{31}$ On the other hand, Mohamed et al..$^{32}$ have described in pituitary PD follicles of smaller size (major colloidal diameter: $12.67 \pm 0.38 \mu \mathrm{m}$ ). In the present work, FSC of PD were pleomorphic and showed short cytoplasmic processes which contacted endocrine cells and blood vessels. The smaller follicle size and the FSC short cytoplasmic 

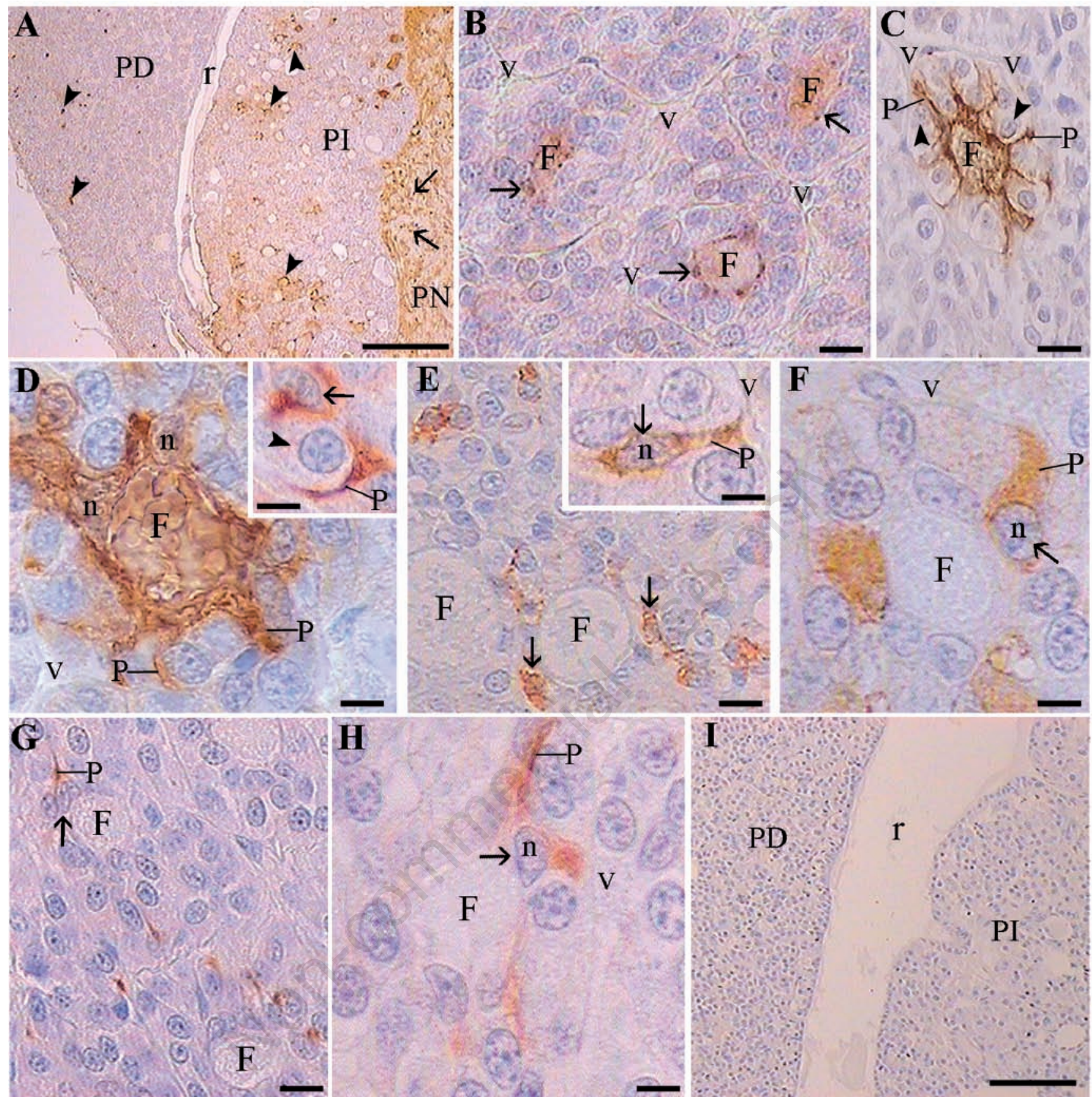

Figure 3. Immunohistochemistry for S-100 protein (A-D), GFAP (E-F) and vimentin (G-H) in pituitary pars distalis of viscacha. (A) The immunostaining for S-100 protein is observed in the FSC and some follicular colloid (arrowheads) of pars distalis (PD) and pars intermedia (PI). The pituicytes (arrows) of pars nervosa (PN) also exhibit immunostaining for this protein. r: Rathke's pouch. (B) FSC (arrows) immunostained with anti-S-100 protein forming follicles surrounded by blood vessels (v). The follicular colloid (F) presents heterogeneous immunostaining for this protein. (C) Short cytoplasmic processes (P) of the FSC are in contact with blood vessels (v) and surround endocrine cells (arrowheads). F: immunostained follicular colloid. (D) Immunostaining for S-100 protein is observed in the nucleus (n), cytoplasm (c) and cytoplasmic process (P) of the FSC. The follicular colloid (F) exhibits a heterogeneous immunostaining pattern. v: blood vessel. Inset: A FSC (arrow) with only immunostained cytoplasm and other with a cytoplasmic process (P) surrounding an endocrine cell (arrowhead). (E-F) Scarce FSC (arrows) are immunostained with anti-GFAP in the cytoplasm around the nucleus. F: follicles without immunostaining for GFAP. Inset and Figure F, Short cytoplasmic processes (P) of FSC in contact with blood vessel (v) are observed. n: nucleus without immunostaining for GFAP. (G-H) A few FSC (arrows) show cytoplasmic immunostaining for vimentin, mainly in the cytoplasmic processes (P). The follicles (F) and nucleus (n) of FSC are not immunostained with anti-vimentin. (I) Negative control of immunoperoxidase staining. PD: pars distalis. r: Rathke's pouch. PI: pars intermedia. Scale bars: $\mathrm{A}=250 \mu \mathrm{m} ; \mathrm{B}-\mathrm{C}=\mathbf{1 2 . 5} \mu \mathrm{m} ; \mathrm{D}-\mathrm{H}$ and Insets $=5 \mu \mathrm{m} ; \mathrm{I}=100 \mu \mathrm{m}$. 

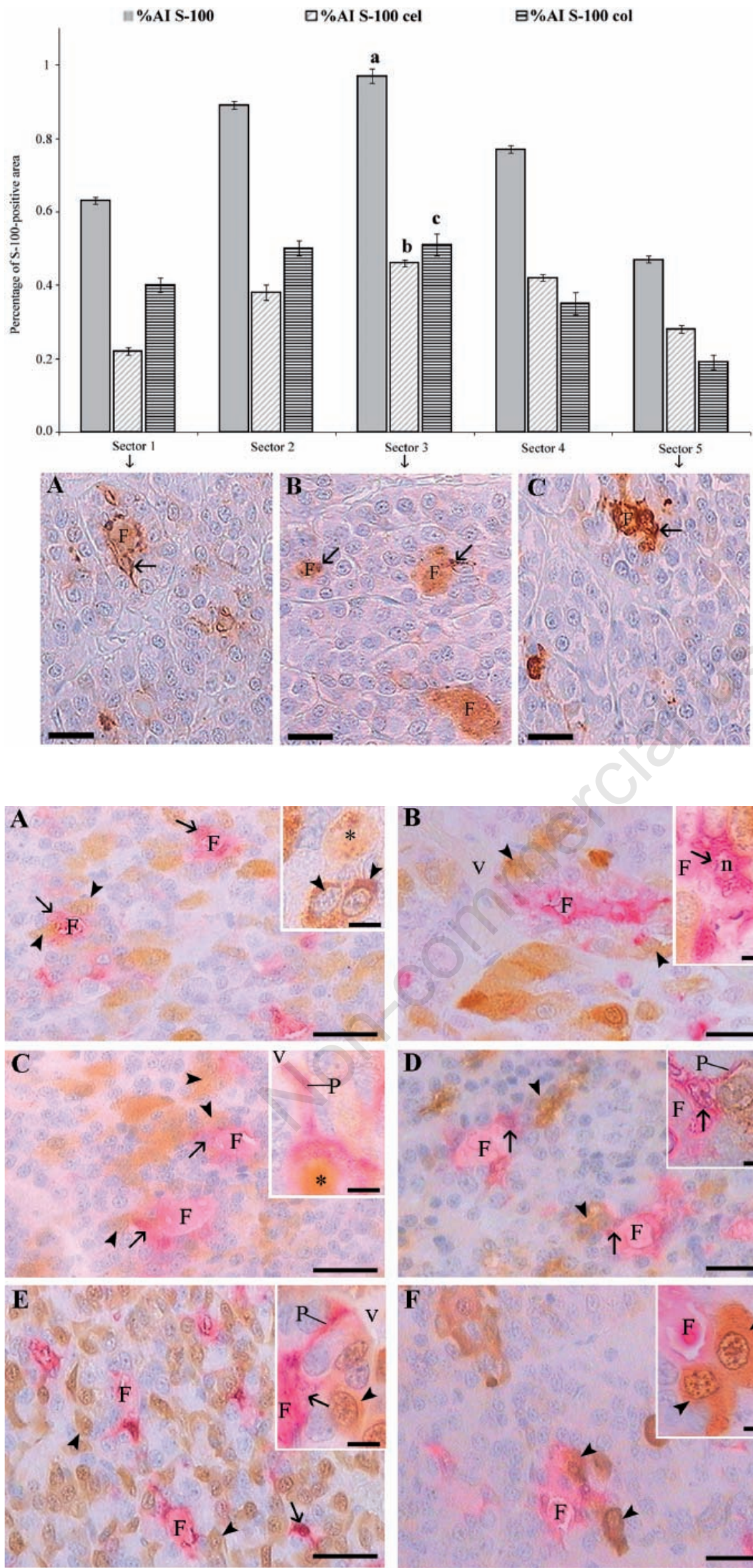
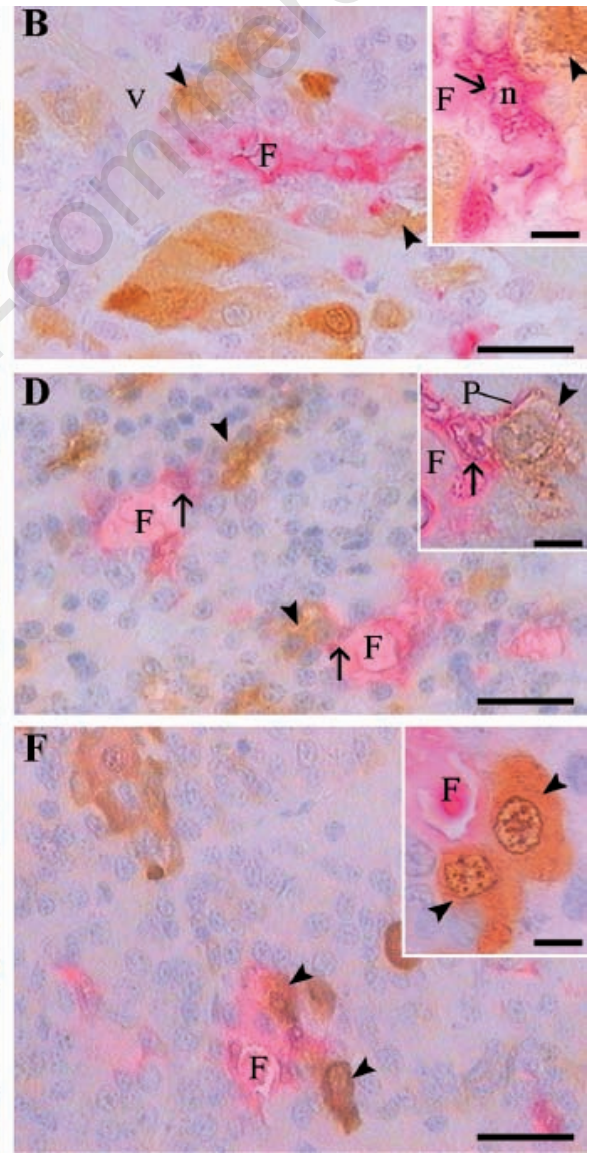

Figure 4. Distribution of S-100 protein in pituitary pars distalis of adult male viscacha. Graph: The values are expressed as mean \pm SEM. \%IA S-100: percentage of $S$ 100-positive total area; \%IA S-100 cel: percentage of S-100-positive cellular area; \%IA S-100 col: percentage of S-100-positive colloidal area. Significant differences were determined by analysis of variance followed by Tukey-Kramer multiple comparison test. \%IA S-100: a, $P<0.01$; 3 versus 1 and 5. \%IA S-100 cel: $b, P<0.01 ; 3$ versus 1 and 5. \%IA $S-100$ col: $c, P<0.01$; 3 versus 5 . The images show details of the pituitary cephalic extremes in the sectors 1 (A), 3 (B) and 5 (C) immunostained with anti-S-100 protein. In sector 3 (B) an increase of the immunopositive area is observed. Arrows: FSC. F: follicular colloids. Scale bars: A-C $=12.5 \mu \mathrm{m}$.
Figure 5. Micrographs of double-immunohistochemistry of anterior pituitary hormones (Prl, FSH, LH, ACTH, GH and TSH; brown) and S-100 protein (fuchsia). (A) A close association between lactotrophs (arrowheads) and FSC (arrow) originating follicles (F) are shown. Inset: Singleimmunostaining for prolactin. Follicular colloid immunostained with anti-Prl (asterisk) and lactotrophs (arrowhead) near the follicle are observed. (B - Inset) The FSHgonadotrophs (arrowheads) are contacting FSC (arrow) and follicles (F). v: blood vessel; n: S-100-positive nucleus of FSC. (C) Several LH-gonadotrophs (arrowheads) are associated to FSC (arrows) and follicles (F). Inset: The cytoplasmic process (P) of FSC is in contact with blood vessel (v). Asterisk: Follicular colloid immunostained with antiLH. (D) The corticotrophs (arrowheads) are located near the FSC (arrows) and follicles (F). Inset: a cytoplasmic process (P) of FSC (arrow) surrounding a corticotroph (arrowhead) is observed. (E) Somatotrophs (arrowheads) exhibit a wide distribution in pituitary pars distalis, but they are only observed in the proximity of follicles (F). Arrow: isolated FSC with a short cytoplasmic process. Inset: Somatotroph (arrowhead), in the second layer limiting the follicle, and a cytoplasmic process (P) of FSC (arrow) reaching the blood vessel $(v)$ are observed. (F - Inset). In the pars distalis caudal extreme, scarce thyrotrophs (arrowheads) in the vicinity of the follicles (F) are observed. Scale bars: A-F = 25 um; Insets of all Figures $=5 \mu \mathrm{m}$. 

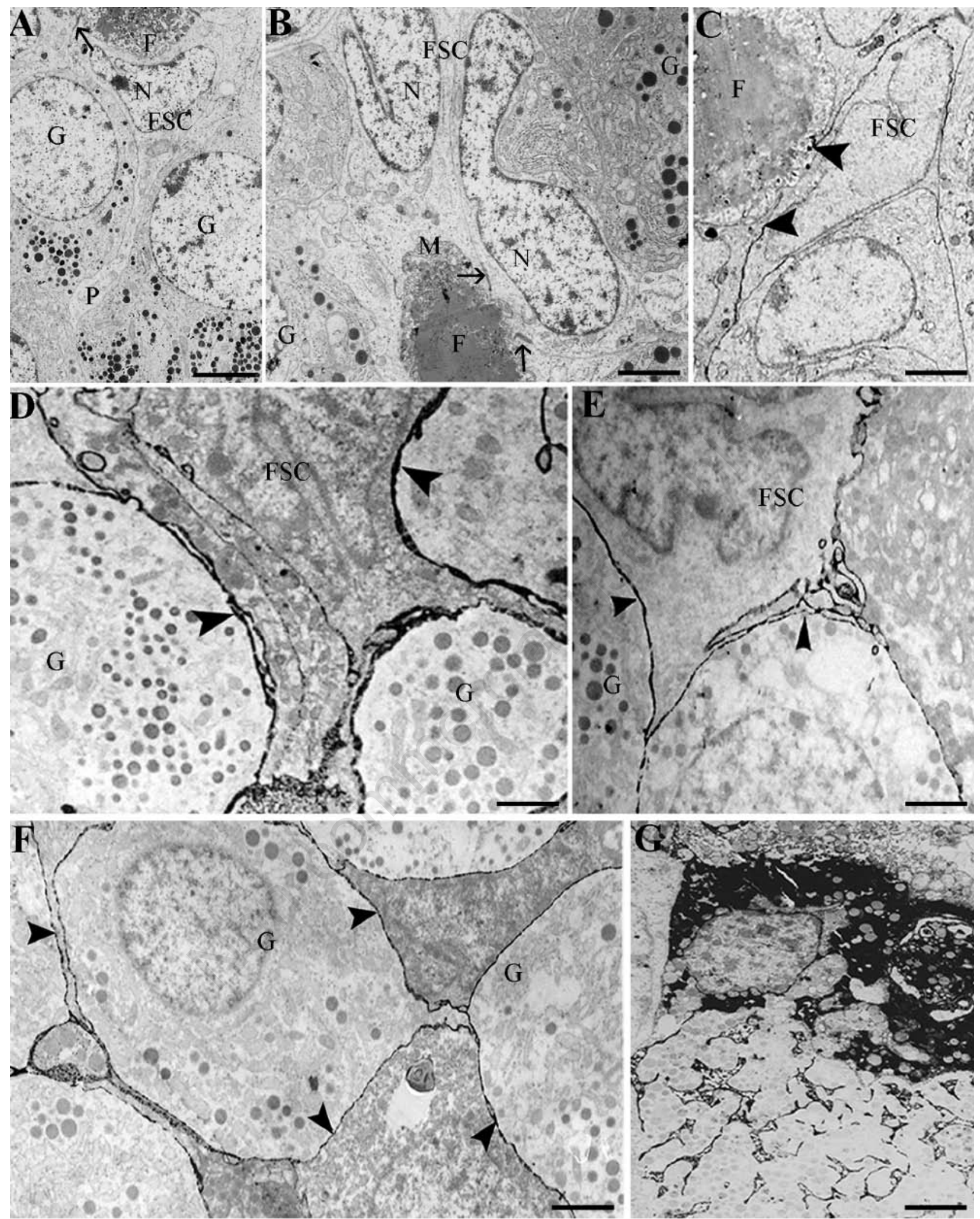

Figure 6. Electron micrographs of pituitary pars distalis of adult male viscachas. (A-B) Conventional transmission electron microscopy. The folliculostellate cells (FSC) form follicles (F) have irregular nuclei (N), scarce cytoplasm with short cytoplasmic process (P) and absence of secretory granules. The different granulated cellular types (G) are closely associated with FSC, but without contacting the follicular lumen. Well developed junctional complex (arrows) are observed at the apical lateral surface of the FSC. These cells exhibit long microvilli (M) that protrude into the follicular lumen (F). (C-G) Transmission electron microscopy with lanthanum. (C) The tracer stops below the junctional complex (arrowheads) without penetrating in the follicular colloid. (D-F) Lanthanum freely penetrates into the intercellular spaces (arrowheads) between granulated endocrine cells (G) and FSC. The tracer does not penetrate into any healthy cellular type. On the contrary, lanthanum is observed inside the cells in different states of involution and degeneration $(G)$. Scale bars: $A=7 \mu \mathrm{m} ; B-C=4 \mu \mathrm{m} ; D-F=3.33 \mu \mathrm{m} ; G=2 \mu \mathrm{m}$. 
processes are probably due to the abundant irrigation and close relation between vascularization and follicles that characterize the PD. FSC expressed the S-100 protein and occasionally GFAP and vimentin, which are considered as markers of glial, astrocyte and immature glial cells, respectively. These results in PD support our previous hypothesis for viscacha $\mathrm{PI}^{31}$ that FSC have a neuroectodermic origin. Moreover, the differential expression of the tested proteins and the immunostaining patterns suggest the presence of FSC in different functional stages, as has also been proposed for viscacha $\mathrm{PI}^{31}$ and for other species. ${ }^{7,11}$ Vimentin-positive FSC might represent a small reserve population of these cells in an immature state. It has been reported that FSC generate follicles and synthesize part of the follicular colloid. ${ }^{3,416-18}$ The characterization of these colloidal substances is necessary to establish the FSC precise functions. ${ }^{18}$ It has been suggested that colloid is derived from the interstitial fluid of the PD. ${ }^{45}$ An alternative hypothesis suggested that the follicular colloid arises as a by-product of cellular degradation. ${ }^{46,47}$ On the other hand, it has been reported that the S-100 protein acts inside the cells as a calcium-sensor protein implicated in the calcium signal transduction and, outside the cells, as a ligand for specific surface receptors in various cellular types. ${ }^{48}$ Moreover, it has been proposed that S-100 proteins perform intra and extracellular roles in the regulation of cellular motility, growth, transcription, differentiation, survival and cycle. ${ }^{48,49}$ In viscacha PI, Acosta and Mohamed $^{31}$ have shown the expression of the S-100 protein in FSC and follicular colloid. In addition, our result in viscacha $\mathrm{PD}$ also suggests that the intra and extracellular occurrence indicate a differential function of this protein depending on localization.

Mohamed et al. ${ }^{32}$ have postulated that the FSC of viscacha PD might be phagocytes and, moreover, that they have a function in the secretion and absorption of colloid. In this work, we showed the presence of Prl and LH in some follicular colloid, which could be due to remaining LH-gonadotrophs and lactotrophs secretory granules as a product of cellular degradation and phagocytotic activity of FSC. This could also account for the presence of the S-100 protein, although it cannot be discarded that this protein may be liberated from FSC to the follicular lumen. The secretion of the S-100 protein by FSC has been reported in rat pituitary..$^{50}$ However, there is scarce information about the functional implication of the secretion of this protein by FSC. ${ }^{48}$ Few studies have been found in the literature that describe the distribution of FSC. Sato et al. ${ }^{12}$ showed that the distribution of these cells in rat varies with vascularization, suggesting that they might be involved in the modulation of PD endocrine activity. In addi- tion, in aging pig pituitary lactotrophs and occasionally LH-gonadotrophs have been reported to be closely associated to the follicles generated by FSC. $^{51}$ In pituitary of guinea pig, mainly somatotrophs, some corticotrophs and, to a lower extent, other types of hormone secreting cells have been found to delimit follicles. In this species, the follicular colloid did not present immunostaining for any of the pituitary hormones. ${ }^{17}$ The morphometric parameters analyzed in our work indicated that S-100-positive FSC are not randomly distributed in the PD parenchyma. On the other hand, lactotrophs, gonadotrophs and corticotrophs exhibited a close relation with FSC and follicles, while somatotrophs and thyrotrophs were less associated to follicular structures. FSC spatial distribution and association with endocrine cells suggest a dynamic communication between these cellular types and differences in the paracrine regulation function of FSC in viscacha PD. In viscacha, permeability to lanthanum and communication with Rathke's pouch has been demonstrated in $\mathrm{PI}{ }^{28}$ In this study, the permeability to this tracer is shown in the PD parenchyma, suggesting the existence of an extensive and permeate network of intercommunicated intercellular spaces between the endocrine cells and FSC. Our findings, together with those of Piezzi et al. ${ }^{28}$ demonstrate the existence of a communication network between PD, the lumen of the pituitary pouch and PI. This link might function as an alternative route to vascular irrigation and could be involved in the regulation of secretory activity in both adenohypophysial zones. In addition, FSC exhibited junctional complexes, which stopped the penetration of lanthanum, and abundant microvilli in the apical lateral surface, suggesting that they can form and mobilize the follicular colloid. Furthermore, degenerating cells reached by lanthanum may represent an early stage in the process of colloid formations in pituitary PD of viscacha. To sum up, 1) FSC exhibited differential expression for the S-100 protein, GFAP and vimentin, indicating the presence of cells in different physiological stages; 2 ) the expression of these proteins supports the hypothesis of the neuroectodermic origin of FSC; 3) the S-100 protein was expressed in FSC and the follicular colloid, suggesting different functions of this protein according to its localization; 4) the FSC spatial distribution, their association with endocrine cells, and the generation of an intercellular communication network suggest that these cells are involved in pituitary paracrine regulation. Therefore, the PD of viscacha constitutes a novel and interesting model for further studies of FSC. In addition, the analysis of the $\mathrm{S}-100$ protein accumulated in the follicular colloid could also be of great interest in understanding its extracellular function in the pituitary gland.

\section{References}

1. Marin F, Stefaneanu L, Kovacs K. Folliculostellate cells of the pituitary. Endocr Pathol 1991;2:180-92.

2. Allaerts W, Vankelecom H. History and perspectives of pituitary folliculo-stellate cell research. Eur J Endocrinol 2005;153:1-12.

3. Luziga C, Yoshimi Y, Yoichiro $\mathrm{H}$, et al. Phagocytotic removal of apoptotic endocrine cells by folliculostellate cells and its functional implications in clusterin accumulation in pituitary colloids in helmeted guinea fowl (Numida meleagris). Acta Histochem 2006;108:69-80.

4. Luziga C, Kipanyula MJ, Mbassa G, Koichi M. Colloid in the anterior pituitary of helmet guinea fowl (Numida meleagris galeata): morphometric analysis and pattern of occurrence in relation to apoptosis. Vet Res Commun 2009;33:681-91.

5. Devnath S, Inoue K. An insight to pituitary folliculo-stellate cells. J Neuroendocrinol 2008;20:687-91.

6. Soji T, Sirasawa N, Kuroni C, Yashiro T, Herbert DC. Immunohistochemical study of the post-natal development of the folliculo-stellate cells in the rat anterior pituitary gland. Tissue Cell 1994;26:1-8.

7. Cardin J, Carbajal ME, Vitale ML. Biochemical and morphological diversity among folliculo-stellate cells of the mink (Mustela vison) anterior pituitary. Gen Comp Endocr 2000;120:75-87.

8. Inoue K, Mogi C, Ogawa S, et al. Are folliculo-stellate cells in the anterior pituitary gland supportive cells or organ-specific stem cells? Arch Physiol Biochem 2002; 110:50-3.

9. Marettová E, Maretta M. Immunohistochemical localization of S-100 protein in the pig pituitary gland. Anat Histol Embryol 2004;33:344-7.

10. Nakajima T, Yamaguchi H, Takahashi K. S-100 protein in folliculostellate cells of the rat pituitary anterior lobe. Brain Res 1980;191:523-31.

11. Marin F, Boya J, López-Carbonell A, Borregón A. Immunohistochemical localization of intermediate filament and S-100 proteins in several non-endocrine cells of the human pituitary gland. Arch Histol Cytol 1989;52:241-8.

12. Sato G, Shirasawa N, Sakuma et al. Intercellular communications within the rat anterior pituitary XI: an immunohistochemical study of distributions of S-100 positive cells in the anterior pituitary of the rat. Tissue Cell 2005;37:269-80.

13. Chowdhury VS, Yoshimura Y. Changes in the population of immunoreactive S-100positive folliculo-stellate cells in hens dur- 
ing induced molting. Poult Sci 2002;81: 556-60.

14. Marin F, Boya J, López-Carbonell A. Immunocytochemical localization of vimentin in stellate cells (folliculo-stellate cells) of the rat, cat and rabbit pituitary pars distalis. Anat Embryol 1989;179:491-5.

15. Méndez A, Martín de las Mulas J, Bautista $\mathrm{MJ}$, et al. Comparative immunohistochemical study of stellate cells in normal canine and equine adenohypophyses and in pituitary tumors. J Comp Path 1998;118:29-40.

16. Kagayama M. The follicular cell in the pars distalis of the dog pituitary gland: an electron microscope study. Endocrinology 1965;77:1053-60.

17. Kameda Y. Occurrence of colloid-containing follicles in the pars distalis of pituitary glands from aging guinea pigs. Cell Tissue Res 1991;263:115-24.

18. Ogawa S, Ishibashi Y, Sakamoto Y, et al. The glycoproteins that occur in the colloids of senescent porcine pituitary glands are clusterin and glycosylated albumin fragments. Biochem Biophys Res Commun 1997;234:712-8

19. Saland LC. Extracellular spaces of the rat pars intermedia as outlined by lanthanum tracer. Endocrinology 1979;196:355-60.

20. Allaerts W, Denef C. Regulatory activity and topological distribution of folliculostellate cells in rat anterior pituitary aggregates. Neuroendocrinology 1989;49: 409-18.

21. Redford KH, Eisenberg JF. Mammals of the neotropics: The southern cone. Vol 2. The University of Chicago Press, Chicago 1992, pp 430.

22. Jackson JE, Branch LC, Villarreal D. Lagostomus maximus. Mammalian Species 1996;543:1-6.

23. Fuentes LB, Caravaca N, Pelzer LE, et al. Seasonal variations in the testis and epididymis of viscacha (Lagostomus maximus maximus). Biol Reprod 1991;45:4937.

24. Fuentes LB, Calvo JC, Charreau EH, Guzman JA. Seasonal variations in testicular LH, FSH, and PRL receptors, in vitro testosterone production, and serum testosterone concentration in adult male viscacha (Lagostomus maximus maximus). Gen Comp Endocr 1993;90:133-41.

25. Muñoz E, Fogal T, Dominguez S, et al. Ultrastructural and morphometric study of the Sertoli cell of the viscacha (Lagostomus maximus maximus) during the annual reproductive cycle. Anat Rec 2001;262:176-85.

26. Aguilera Merlo C, Muñoz E, Dominguez S, et al. Epididymis of viscacha (Lagostomus maximus maximus): morphological changes during the annual reproductive cycle. Anat Rec 2005;282:83-92.

27. Filippa V, Penissi A, Mohamed F. Seasonal variations of gonadotropins in the pars distalis male viscacha pituitary. Effect of chronic melatonin treatment. Eur J Histochem 2005;49:291-300.

28. Piezzi RS, Cavicchia JC, Scardapane L, et al. Marginal cells of the viscacha pituitary cleft. A correlate study by thin-sectioning, lanthanum intercellular tracer and freezefracture techniques. Microsc Electrón Biol Celular 1985;9:193-203.

29. Dominguez S, Piezzi RS, Scardapane L, Guzmán J. Permeability of pineal gland of viscacha (Lagostomus maximus maximus) to the lanthanum hydroxide. J Pineal Res 1990;8:367-74.

30. Morales A, Cavicchia JC. Seasonal changes of the blood-testis in viscacha (Lagostomus maximus maximus): a freese-fracture and lanthanum tracer study. Anat Rec 1993;236:459-64.

31. Acosta M, Mohamed F. Pituitary pars intermedia of male viscacha (Lagostomus maximus maximus): a morphometric study of seasonal and age-related changes in immunohistochemistry. Cells Tissues Organs. 2009;190:219-29.

32. Mohamed F, Fogal T, Dominguez S, et al. Colloid in the pituitary pars distalis of viscacha (Lagostomus maximus maximus): ultrastructure and occurrence in relation to season, sex, and growth. Anat Rec 2000;258:252-61.

33. Filippa V, Mohamed F. ACTH cells of pituitary pars distalis of viscacha (Lagostomus maximus maximus): immunohistochemical study in relation to season, sex, and growth. Gen Comp Endocr 2006;146:21725.

34. Filippa V, Mohamed F. Immunohistochemical study of somatotrophs in pituitary pars distalis of male viscacha (Lagostomus maximus maximus) in relation to the gonadal activity. Cells Tissues Organs 2006;184:188-97.

35. Filippa V, Mohamed F. Immunohistochemical and morphometirc study of pituitary pars distalis thyrotrophs of male viscacha (Lagostomus maximus maximus): seasonal variations and effect of melatonin and castration. Anat Rec 2008;291:400-9.

36. Filippa V, Mohamed F. Morphological and morphometric changes of pituitary lactotrophs of viscacha (Lagostomus maximus maximus) in relation to reproductive cycle, age, and sex. Anat Rec Forthcoming 2009.

37. Llanos AC, Crespo JA. Ecología de la vizcacha (Lagostomus maximus maximus) en el nordeste de la provincia de Entre Ríos. Rev Investig Agric. Extra Nueva Serie 1954;10:5-95.

38. Branch LC, Villareal D, Fowler GS.
Recruitment, dispersal, and group fusion in a declining population of the plains vizcacha (Lagostomus maximus; Chinchillidae). J Mammal 1993;74:9-20.

39. Karnovsky MJ. A formaldehyde-glutaraldehyde fixative of the high osmolarity for the use in electron microscopy. J Cell Biol 1965;27:137-8.

40. Revel JP, Karnovsky MJ. Hexagonal array of subunits in intercellular junctions of the mouse heart and liver. J Cell Biol 1967; 33:c7-c12.

41. Millonig G. A modified producer for lead staining of thin sections. J Biophys Biochem Cytol 1961;11:736-9.

42. Tsuchida T, Nagao S, Ohmoto T. The fine structure of the $S-100$ protein positive cells in the rat pituitary gland: an immunoelectron microscopic study. Brain Res 1991; 564:164-6.

43. Amano 0, Yoshitake Y, Nishikawa K, Iseki S. Immunocytochemical localization of basic fibroblast growth factor in the rat pituitary gland. Arch Histol Cytol 1993;56: 269-76.

44. Ogawa A, Sugihara S, Nakanishi Y, et al. Intermediate filament expression in nonneoplastic pituitary cells. Virchows Arch B Cell Pathol Incl Mol Pathol 1990;58:331-40.

45. Vila-Porcile E. The network of the folliculostellate cells and the follicles of the adenohypophysis in the rat (pars distalis). Z Zellforsch Mikrosk Anat 1972;129:328-69.

46. Horvath E, Kovacs K, Penz G, Ezrin C. Origin, possible function and fate of "follicular cells" in the anterior lobe of the human pituitary. Am J Pathol 1974;77:199212.

47. Ciocca DR, González CB. The pituitary cleft of the rat: an electron microscopic study. Tissue Cell 1978;10:725-33.

48. Donato R. S-100: a multigenic family of calcium-modulated proteins of the EFhand type with intracellular and extracellular functional roles. Int J Biochem Cell B 2001;33:637-68.

49. Santamaría-Kisiel L, Rintala-Dempsey AC, Shaw GS. Calcium-dependent and - independent interactions of the S100 protein family. Biochem J 2006;396:201-14.

50. Ishikawa $H$, Nogami $H$, Shirasawa N. Novel clonal strains from adult rat anterior pituitary producing S-100 protein. Nature. 1983;303:711-3.

51. Ogawa S, Couch EF, Kubo M, et al. Histochemical study of follicles in the senescent porcine pituitary gland. Arch Histol Cytol 1996;59:467-78. 